Acta vet. scand. $1978,19,341-353$.

From the Department of Obstetrics and Gynaecology and the Ambulatory Clinic, Hautjärvi, and the Department of Animal Hygiene, Helsinki, College of Veterinary Medicine, Finland.

\title{
INCIDENCE OF SOME DISEASES IN CONNECTION WITH PARTURITION IN DAIRY COWS
}

\author{
By \\ K. Roine and H. Saloniemi
}

\begin{abstract}
ROINE, K. and H. SALONIEMI: Incidence of some diseases in connection with parturition in dairy cows. Acta vet. scand. 1978, 19, 341-353. - The incidence of dystocia, uterine, prolapse, retained placenta, puerperal metritis and vaginal prolapse was investigated in 283 herds over a period of eight years (about 2,590 cows per year). The incidence of dystocia $(0.012$ cases per cow and year), of uterine prolapse $(0.002)$ and puerperal metritis $(0.002)$ varied with the monthly variation in parturition. Retained placenta (incidence 0.025) occurred more frequently in March-June relative to parturition. The cows then calving were older than average. Vaginal prolapse (incidence 0.002) was also commoner in the spring months. Herds with a high incidence of retained placenta also showed more mastitis, ketosis and parturient paresis.
\end{abstract}

disease incidence; dystocia; uterine prolapse; retained placenta; puerperalmetritis; vaginal prolapse; herd size; dairy cows.

The incidence of diseases has attracted increasing scientific interest in all the Nordic countries in recent years. In Sweden, for instance (Bäckström et al. 1975), and in Norway (Anon. 1976), there is extensive use of systems of compiling information on disease incidence. Some of the first extensive studies of the incidence of diseases in cattle were carried out in the 1960's in Denmark (Rasbech et al. 1967, 1968, Elleby et al. 1969) and in Sweden (Ekesbo 1966). Studies concerning disease incidence published in Finland are based on the material of the ambulatory clinic of the College of Veterinary Medicine (Roine et al. 1971, Saloniemi \& Roine 1976).

Studies have not been published in the Nordic countries of diseases in connection with parturition (dystocia, uterine pro- 
lapse, retained placenta, puerperal metritis and vaginal prolapse) as an integrated group. Diseases of this group have been noted, for instance, in the above mentioned studies, while particular studies have been made on the incidences of retained placenta (e.g. Cohen 1956, Brands 1966, Dyrendahl et al. 1977), and of dystocia (e.g. Grommers et al. 1965). Only scattered information exists in Finland about this group of diseases, and the present study consequently aims at clarifying the incidences of these diseases and some of the factors affecting such incidences. This paper is part of a more extensive investigation of disease incidence in cows which includes an analysis of the economic significance of diseases. Where diseases in connection with parturition are concerned, the purpose is to analyse their effects on fertility in continued investigations.

\section{MA'TERIALS AND METHODS}

The disease incidence data on 283 herds within the district of the ambulatory clinic of the College of Veterinary Medicine were collected over a period of eight years (1968-1975). The study covers the farms within the district of the clinic on which the veterinary services were provided solely by the clinic, and on which as little change as possible has occurred in recent years in the numbers of cows. The farms had a total of some 2,590 cows in each year. The data on diseases were noted on the farm card of the clinic at every visit to a farm (Roine 1969). The material includes only those cases treated in connection with visits to farms. The diagnoses are clinical diagnoses made by conventional methods. Solely the primary disease is taken into account, and repeated treatment of the disease is not included.

The studied diseases have been defined as follows:

Dystocia : difficult or abnormal parturition, aided by a veterinarian.

U t e rine prolapse : cases of inversio et prolapsus uteri of varying degrees.

$\mathrm{Re} t \mathrm{a}$ in ed p I a c e $\mathrm{nta}$ : the placenta is not expelled spontaneously within $24 \mathrm{hrs}$. after parturition.

Puerperal metritis: acute metritis with general and local symptoms during puerperium.

$\mathrm{Vag}$ i n a l p r o l a p s e : vaginal prolapse of various degrees, requiring veterinary aid. 
The size of the material, i.e. the numbers of cases of each disease, is shown in Table 1 , which also gives the percentages of these diseases in all cases of diseases treated by a veterinarian during the farm visits $(11,443$ cases $)$.

Table 1. The research material and the proportion therein of all diseases treated by a veterinarian during farm visits.

\begin{tabular}{lcc}
\hline Disease & $\begin{array}{c}\text { Number } \\
\text { of cases }\end{array}$ & $\begin{array}{c}\text { Proportion of total } \\
\text { number of diseases, \% }\end{array}$ \\
\hline Dystocia & 247 & 2.16 \\
Uterine prolapse & 48 & 0.42 \\
Retained placenta & 526 & 4.60 \\
Puerperal metritis & 52 & 0.45 \\
Vaginal prolapse & 45 & 0.39 \\
\hline Total & 918 & 8.02 \\
\hline
\end{tabular}

From the cards were taken the diagnosis, the year and month, the number of cows in the herd, the type of housing, and whether the farm participated in milk recording, and the information was entered on a punch card for each farm. The data were processed at the Agricultural Data Processing Centre by conventional statistical methods. The incidences of diseases in every investigated year, i.e. the number of cases per cow per year, were calculated for each herd. The disease incidences for the different sizes of herd, the types of housing and the farms were calculated and the significance of the differences was analysed by means of one-way analysis of variance. The correlation coefficients between the variables were also calculated. Correlations were confirmed by Chi-square test of independence. Least squares analysis of variance (Harvey 1966) was performed for total incidence and puerperal metritis in respect of housing type and herd size. The annual and monthly variation was calculated in respect of the number of cases, testing being done by Chi-square test. In the comparison of the seasonal variations in disease incidence with the seasonal variation in parturition, use was made of the parturition data of milk recording herds in the district of the Uusimaa Agricultural Centre for 1967-75 (some 12,000 cows per year), for which the monthly averages were calculated (Table 5). The parturition ordinal in each month was calculated from the milk recording material for 1976, covering the entire country (Table 2). 
T a b l e 2. Parturition ordinal of cows calving in different months. 114,916 Finnish Ayrshire cows that had calved twice or more, the official control statistics for 1976, average parturition ordinal 3.84.

\begin{tabular}{|c|c|c|c|c|c|c|c|c|c|c|c|c|}
\hline Month & I & II & III & IV & V & VI & VII & VIII & IX & $\mathbf{x}$ & XI & XII \\
\hline $\begin{array}{l}\text { Number } \\
\text { of } \\
\text { calvings }\end{array}$ & 3.73 & 3.76 & 3.98 & 4.03 & 4.06 & 4.08 & 3.82 & 3.47 & 3.48 & 3.60 & 3.82 & 3.84 \\
\hline
\end{tabular}

The cows to which the incidence data relate are of the Finnish Ayrshire breed to some $90 \%$. Most of those remaining are crossbred, and a minor proportion are Finncattle and Friesians.

\section{RESULTS}

The average incidences per herd, and the average incidences for the material as a whole, are shown in Table 3 . The incidence of disease connected with parturition in the material as a whole was 0.044 .

Table 3. The incidence of diseases counted as an average incidence per herd and total incidence.

\begin{tabular}{lcc}
\hline Disease & $\begin{array}{c}\text { Average incidence } \\
\text { per herd }\end{array}$ & Total incidence \\
\hline Dystocia & 0.013 & 0.012 \\
Uterine prolapse & 0.002 & 0.002 \\
Retained placenta & 0.028 & 0.025 \\
Puerperal metritis & 0.002 & 0.002 \\
Vaginal prolapse & 0.002 & 0.002 \\
\hline Puerperal diseases & 0.047 & 0.044 \\
\hline
\end{tabular}

The annual number (Table 4) for diseases connected with parturition varied in a statistically significant way $\left(\chi^{2}=20.5\right.$, d.f. $=7, \mathrm{P}<0.01$ ), as did the number of cases of retained placenta $\left(\chi^{2}=23.3\right.$, d.f. $\left.=7, P<0.01\right)$. The annual variations in dystocia cases could be due to chance $\left(\chi^{2}=8.6, d . f .=7, P>0.2\right)$.

The monthly variation in diseases connected with parturition is a consequence of the great seasonal variation in calving (Table 5 ), and the seasonal variation in dystocia actually does correspond with the seasonal variation in calving $\left(x^{2}=14.8\right.$, d.f. $=$ $11, P>0.1)$. The monthly variation in retained placenta differs very significantly from the monthly variation in calving $\left(\chi^{2}=\right.$ 
T a b l e 4. Number of diseases in the different years.

\begin{tabular}{lcccccr}
\hline Year & Dystocia & $\begin{array}{c}\text { Uterine } \\
\text { prolapse }\end{array}$ & $\begin{array}{c}\text { Retained } \\
\text { placenta }\end{array}$ & $\begin{array}{c}\text { Puerperal } \\
\text { metritis }\end{array}$ & $\begin{array}{c}\text { Vaginal } \\
\text { prolapse }\end{array}$ & Total \\
\hline 1968 & 36 & 5 & 51 & 5 & 4 & 101 \\
1969 & 37 & 4 & 66 & 6 & 6 & 119 \\
1970 & 23 & 3 & 51 & 6 & 1 & 84 \\
1971 & 26 & 8 & 49 & 9 & 13 & 105 \\
1972 & 23 & 9 & 74 & 6 & 6 & 118 \\
1973 & 32 & 6 & 92 & 7 & 9 & 146 \\
1974 & 38 & 8 & 71 & 3 & 2 & 122 \\
1975 & 32 & 5 & 72 & 10 & 4 & 123 \\
\hline
\end{tabular}

52.1, $\mathrm{P}<0.001$, Fig. 1). Cases of uterine prolapse and puerperal metritis occur in the two halves of the year in the same ratio as do calvings $\left(\chi^{2}=0.53\right.$ and 0.71 , d.f. $\left.=1,0.3<\mathrm{P}<0.5\right)$; but the cases of vaginal prolapse are significantly more frequent in the first half of the year $\left(\chi^{2}=6.69\right.$, d.f. $\left.=1, P<0.01\right)$. The parturition ordinal of cows calving during March-June is greater than average (Table 2).

When the herds were classified by number of cows, the incidence in respect of the various diseases was as shown in Table 6. The incidences of dystocia, uterine prolapse and vaginal prolapse did not differ significantly among the varying sizes of herd. The incidence of retained placenta did not differ quite significantly, on the basis of variance analysis, among the various

Table 5. Number of diseases in different months, and the percentage distribution of calvings used for comparison.

\begin{tabular}{lrcccrrr}
\hline Month & Dystocia & $\begin{array}{c}\text { Uterine } \\
\text { prolapse }\end{array}$ & $\begin{array}{c}\text { Retained } \\
\text { placenta }\end{array}$ & $\begin{array}{c}\text { Puerperal Vaginal } \\
\text { metritis }\end{array}$ & Total & $\begin{array}{r}\text { Distri- } \\
\text { pution of } \\
\text { calvings }\end{array}$ \\
\hline I & 21 & 2 & 28 & 2 & 4 & 57 & 8.7 \\
II & 26 & 5 & 43 & 11 & 5 & 90 & 8.0 \\
III & 31 & 5 & 79 & 6 & 7 & 128 & 12.5 \\
IV & 40 & 9 & 95 & 8 & 10 & 162 & 13.7 \\
V & 27 & 5 & 66 & 3 & 5 & 106 & 9.1 \\
VI & 10 & 4 & 38 & 2 & 3 & 57 & 4.4 \\
VII & 15 & 2 & 30 & 3 & 1 & 51 & 4.7 \\
VIII & 12 & 1 & 26 & 2 & 0 & 41 & 6.7 \\
IX & 9 & 2 & 23 & 4 & 2 & 40 & 7.2 \\
X & 19 & 5 & 31 & 5 & 0 & 60 & 8.6 \\
XI & 23 & 4 & 35 & 4 & 2 & 68 & 8.0 \\
XII & 14 & 4 & 32 & 2 & 6 & 58 & 8.4 \\
\hline
\end{tabular}




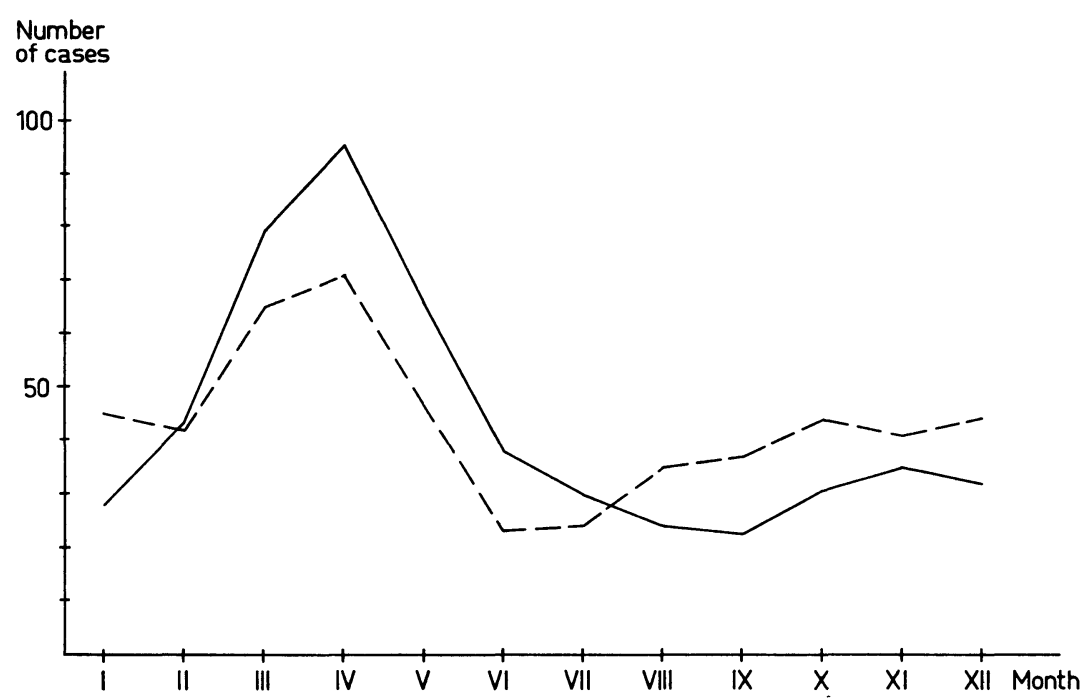

Figure 1. Monthly distribution of retained placenta observed (solid line) and theoretically calculated distribution of retained placenta based on distribution of calvings (dotted line).

T a b l e 6. Incidence of disease in herds of different sizes.

\begin{tabular}{lccccccc}
\hline $\begin{array}{l}\text { Herd } \\
\text { size }\end{array}$ & $\begin{array}{c}\text { Number } \\
\text { of herds }\end{array}$ & Dystocia & $\begin{array}{c}\text { Uterine } \\
\text { prolapse }\end{array}$ & $\begin{array}{c}\text { Retained } \\
\text { placenta }\end{array}$ & $\begin{array}{c}\text { Puerperal } \\
\text { metritis }\end{array}$ & $\begin{array}{c}\text { Vaginal } \\
\text { prolapse }\end{array}$ & Total \\
\hline $1-5$ & 68 & 0.014 & 0.001 & 0.030 & 0.001 & 0.002 & 0.048 \\
$6-10$ & 132 & 0.013 & 0.002 & 0.031 & 0.001 & 0.003 & 0.051 \\
$11-15$ & 53 & 0.011 & 0.002 & 0.022 & 0.002 & 0.001 & 0.038 \\
$16-20$ & 17 & 0.009 & 0.002 & 0.021 & 0.007 & 0.001 & 0.041 \\
$21-$ & 13 & 0.010 & 0.004 & 0.015 & 0.004 & 0.004 & 0.037 \\
\hline Mean & & 0.013 & 0.002 & 0.028 & 0.002 & 0.002 & 0.047 \\
F & & 0.78 & 0.79 & 0.32 & 4.79 & 1.47 & 2.07 \\
P & & $>0.05$ & $>0.05$ & $>0.05$ & $<0.01$ & $>0.05$ & $>0.05$ \\
r & & -0.03 & 0.04 & -0.06 & 0.06 & -0.01 & 0.05 \\
P & $>0.05$ & $>0.05$ & $<0.01$ & $<0.01$ & $>0.05$ & $<0.05$ \\
\hline
\end{tabular}

groups of herd size, but the correlation $(r=-0.06)$ is significant $(\mathrm{P}<0.01)$. The incidence of puerperal metritis increases with increasing size of herd $(r=0.06, P<0.01)$.

A total of 270 of the herds were in stalls with long standing, 11 in stalls with short standing, and two in littered loose housing. In stalls with short standing the size of herd was significantly larger (19.8 cows) than it was in stalls with long standing 
(8.9 cows). When least squares analysis of variance was applied to the total incidence of diseases connected with parturition, to estimate the effect of type of housing and size of herd, it was found that neither factor significantly affects the incidence: $F$ (type of housing) $=0.90, P>0.05$ and $F$ (size of herd) $=2.06, P>0.05$. The means of the total incidences of diseases connected with parturition, estimated by the least squares method, were in the different types of cowshed: stalls with long standing $0.045 \pm 0.002$, stalls with short standing 0.042 \pm 0.010 and littered loose housing $0.014 \pm 0.23$. As the puerperal metritis incidence increased with increasing size of herd, the respective analysis for it was worked out. According to this analysis, the size of herd did affect the incidence but the type of housing did not: $F$ (type of housing $=0.77, P>0.05$ and $F$ (size of herd) $=3.48, \mathrm{P}<0.05$.

On the farms with official milk recording ( 89 farms), the incidence of retained placenta and of puerperal metritis was greater than on other farms, and the total incidence of diseases connected with parturition was also greater (Table 6).

T a b l e 7. Incidence of disease in milk recording herds and in other herds.

\begin{tabular}{lcccccccc}
\hline & $\begin{array}{l}\text { Number } \\
\text { of herds }\end{array}$ & Dystocia & $\begin{array}{c}\text { Uterine } \\
\text { prolapse }\end{array}$ & $\begin{array}{c}\text { Retained } \\
\text { placenta }\end{array}$ & $\begin{array}{c}\text { Puerperal } \\
\text { metritis }\end{array}$ & $\begin{array}{l}\text { Vaginal } \\
\text { prolapse }\end{array}$ & Total \\
\hline $\begin{array}{l}\text { Milk } \\
\text { recording } \\
\text { herds }\end{array}$ & 89 & 0.012 & 0.002 & 0.034 & 0.003 & 0.003 & 0.054 \\
$\begin{array}{l}\text { Other herds } \\
194\end{array}$ & 0.013 & 0.002 & 0.025 & 0.002 & 0.002 & 0.044 \\
\hline F & & 0.42 & 0.10 & 8.01 & 4.63 & 0.42 & 6.18 \\
P & & & 0.05 & $>0.05$ & $<0.01$ & $<0.05$ & $>0.05$ & $<0.05$ \\
\hline
\end{tabular}

Correlation coefficients were calculated between the incidence of diseases connected with parturition and the incidence of certain other diseases by herd. The correlation coefficients indicate that farms with a high incidence of retained placenta also had a high incidence of : mastitis $(r=0.14, P<0.001)$, ketosis $(r=$ $0.07, \mathrm{P}<0.001)$, parturient paresis $(\mathrm{r}=0.06, \mathrm{P}<0.01)$, dystocia $(\mathrm{r}=0.05, \mathrm{P}<0.05)$, and puerperal metritis $(\mathrm{r}=0.04, \mathrm{P}<0.05)$. The correlation coefficient between the incidences of puerperal metritis and mastitis was $0.05(\mathrm{P}<0.05)$. 


\section{DISCUSSION}

The material gives quite an accurate picture of the incidences of diseases connected with parturition treated by a veterinarian in the clinic district during eight years in 283 farms. As the treatment of the diseases connected with parturition, apart from uterine prolapse, may succeed without the help of a veterinarian, the figures do not give accurate information about the total incidence of such diseases.

In this material the diseases connected with parturition made up $8.0 \%$ of all diseases. Consistent results have been obtained in previous studies from the clinic's district, as Roine et al. (1971) found that retained placenta, dystocia and uterine prolapse together represented $7.4 \%$ of the diseases of cows $(8,238$ cases), and Saloniemi \& Roine (1976) found in a material of 20,515 cases of diseases that retained placenta and dystocia together stood for $7.4 \%$.

Some studies have been published on the incidence of dystocia particularly in connection with experiments on the cross-breeding of cattle. Grommers et al. (1965) found in Holland $10.8 \%$ abnormal parturitions out of 1,391 calvings. Ekesbo (1966) found that the dystocia frequency among 4,949 calvings of the Swedish Friesian cows was $12.2 \%$. Ekesbo found no seasonal variation, nor any difference between the grazing season and the indoor feeding season. In a Danish material of 3,227 cases of dystocia made up $4.2 \%$ of all diseases, disease incidence according to the reckoning employed in that study being 0.013 and the frequency $2.3 \%$ of the number of calvings (Rasbech et al. 1967). Two years later Elleby et al. (1969) found that the incidence of dystocia requiring veterinarian aid was 2.1 cases per 100 cows per year. In a Swedish material (Bäckström et al. 1975) the incidence of dystocia requiring veterinarian aid was 0.011 in 1971 and 1972 and 0.009 in 1973.

The incidence of 0.012 cases per cow per year ascertained in the present study is very much of the same order of magnitude as the results of Rasbech et al. (1967) and Bäckström et al. Although our study did not analyse the numbers of calvings, the results of Grommers et al. and Ekesbo seem distinctly higher than the incidence of dystocia ascertained in this study. The seasonal variation follows the seasonal variation in calving the incidence being not affected by the size of the herd. A slight tendency is discernible towards a veterinarian being called in more frequently when the herds are small. 
In the study by Rasbech et al. (1967) prolapsus uteri made up $0.3 \%$ of the diseases, and it occurred in $0.2 \%$ of the calvings. Elleby et al. found the incidence to be 0.003 and Bäckström et al. likewise 0.003. In a new Norwegian study (Ødegaard 1977) the incidence of uterine prolapse was assumed to be 0.002 to 0.003. According to Ødegaard neither calving month nor season of the year had any influence on the incidence of this disease. In the present study the incidence was found to be 0.002 . The incidence of uterine prolapse did not differ significantly from the distribution of calving, and did not depend significantly on the size of herd or on participation in milk recording.

As a diagnosis, retained placenta has not always been defined consistently. The definition employed herein appears to be the most common (Dyrendahl et al. 1977). The varying practice of farmers in deciding to call in a veterinarian affects the frequency figures in the present study, as it does generally in the studies mentioned. A significant variation among the years was ascertained in this study, and observations from general practice support this result. Some researchers have found no differences between different years (Cohen 1956, Ekesbo), although the annual variation in vitamin and mineral deficiencies in fodder, which has been regarded as an aetiological factor (Schou 1965, Dyrendahl et al.), could be assumed naturally to lead to differences in the incidence of this disease. Brands (1966) found in his study that "the seasonal influence is of very little importance, if it exists at all". In the present study, retained placenta occurred with significantly higher frequency in March-June than could be expected on the basis of the seasonal variation in calving. The cows calving in March-June are, on average, older (Table 2) and the explanation of Dyrendahl et al. for the seasonal variation in the incidence of retained placenta thus probably applies to Finnish conditions too.

The higher incidence of retained placenta during the grazing season which has been recorded by Dyrendahl et al. was not observed in the present study. The number of cases of retained placenta declined over the grazing season although the number of calvings increased towards autumn (Fig. 1).

The incidence of retained placenta, of 0.025 cases per cow per year, ascertained in the present study is lower than the Danish (Rasbech et al. 1967: 0.036, Elleby et al.: 0.063), the Swedish (Bäckström et al.: 0.067) or the Norwegian (Simensen 1976: 
0.055-0.088) results arrived at on the same basis. A significant indicator of the differences may be the different incidence of retained placenta by different breeds of cattle (Ekesbo, Dyrendahl et al., Rasbech el al. 1968). We know of no comparative studies of the disease incidence of the Finnish Ayrshire breed but our observations could indicate a low disposition of this breed to retained placenta.

The higher incidence of retained placenta in small herds and in milk recording herds may be the result of the higher propensity of the herdsman to call in a veterinarian (Saloniemi $\&$ Roine).

Dyrendahl et al. found parturient paresis and ketosis more frequently than average in cows with retained placenta. Seven \% of their cows had acute mastitis at the same time. In the present study no observations were made on individual cows, but in herds with a high incidence of retained placenta there was a higher than average incidence of parturient paresis, ketosis, mastitis, dystocia and puerperal metritis. Saloniemi (1977) found that cows with retained placenta have a higher frequency than average of parturient paresis in the following year. All the mentioned observations support the notion that parturient paresis plays a role in the occurrence of retained placenta.

The number of cases of puerperal metritis is so small that the conclusions cannot be definite. The seasonal variation in the incidence of the disease did not differ significantly from the seasonal variation in parturition, but it differed even less from the seasonal variation in retained placenta. The greater incidence of the disease in larger herds is obviously a result of the fact that retained placenta is not treated but spontaneous expelling is expected, and puerperal metritis is a consequence. The incidence ascertained in the present study is only half the incidence found by Bäckström el al. The difference may be associated with the lowered incidence of retained placenta.

The cases of vaginal prolapse are more frequent in the first half of the year than could be expected on the basis of the seasonal variation in calving. Analysis of age disposition might provide an explanation for this variation. The seasonal variation suggests that most of the cases are treated close to the end of pregnancy. The ascertained incidence of 0.002 is greater than the 0.001 ascertained by Bäckström et al.

The effect of the factors of production environment on the 
incidence of diseases is difficult to demonstrate, and the risk of erroneous conclusions is great. The effect of type of housing on the incidence of puerperal metritis is a good example. Seperately calculated, the incidence of puerperal metritis in stalls with short standing was significantly higher, but the difference was in fact due to the greater size of herd, as the least squares analysis of variance showed. Research into the effects of reproduction environment factors should be further developed, for instance to promote methods of prevention.

\section{REFERENCES}

Anon.: Rapport fra vurderingskomiteen for helsekort 1975. (Report of the committee for the assessment of health cards 1975). Norsk Vet.-T. 1976, 88, 544-551.

Brands, A. F. A.: Einige zoötechnische aspecten van retentio secundinarum bij runderen. (Some zootechnical aspects of retained placenta in cattle). Thesis, Utrecht 1966.

Bäckström, L., J. Mattsson, O. Wallin \& B. Vilson: Praktikjournalförsöket i Skaraborgs län 1971-1973. (Practice journal experiment in the county of Skaraborg 1971-1973). Svensk Vet.-Tidn. 1975, 27, 238-250, 292-300.

Cohen, P.: Een statistisch onderzoek omtrent retentio secundinarum en enige andere, met de voortplanting samenhangende, processen bij het rund. (A statistical investigation covering retained afterbirths and other factors associated with bovine reproduction). Thesis, Utrecht 1956.

Dyrendahl, I., J. Mattsson \& B. Pehrson: Retained placenta in cattleincidence, clinical data and effects on fertility. Zbl. Vet.-Med., Reihe A 1977, 24, 529-541.

Ekesbo, I.: Disease incidence in tied and loose housed dairy cattle. Acta agric. scand. 1966, Suppl. 15.

Elleby, F., P. Jochumsen \& N. H. Veirup: Forekomst af kvægsygdomme i 6 danske kontrolforeninger i 1967/68. (Disease incidence within six Danish milk recording societies). Kgl. Vet.- og Landbohøjsk. Inst. Sterilitetsforskn. Aarsberetn. 1969, 77-90.

Grommers, F. J., A. F. A. Brands \& A. Schoenmakers: Mortaliteit van kalveren bij de partus van Nederlandse runderen. (Mortality of calves at parturition in Dutch cattle). T. Diergeneesk. 1965, 90, $231-244$.

Harvey, W. R.: Least squares analysis of data with unequal subclass numbers. Agric. Res. Service, US Dept. Agric. 1966, ARS 20-8.

Rasbech, N. O., P. Jochumsen \& Ib J. Christiansen: Unders $\phi$ gelser over sygdomsforekomst og bedriftsforhold. 1. Sygdommenes klassificering, hyppighed og fordeling på malkekvægracer. (Investigations into disease incidence and farming conditions. 1. 
Classification, frequency and distribution of diseases within dairy cattle breeds). Kgl. Vet.- og Landbohøjsk. Inst. Sterilitetsforskn. Aarsberetn. 1967, 265-308.

Rasbech, N. O., P. Jochumsen \& N. H. Veirup: Forekomst af kvægsygdomme i 6 danske kontrolforeninger. (Investigations into disease incidence within six Danish milk recording societies). Kgl. Vet.- og Landbohøjsk. Inst. Sterilitetsforskn. Aarsberetn. 1968, $99-111$.

Roine, K.: Potilaskortti praktiikkakäyttöön. (Patient register in ambulatory practice). Suom. Eläinlääk.-L. 1969, 75, 299-302.

Roine, K., P. Kokkola \& E. Pyörälä: Naudan tavallisimmat sairaudet ja niiden kausivaihtelu. (The most common diseases in cattle and their seasonal incidence). Suom. Eläinlääk.-L. 1971, 77, $276-280$.

Saloniemi, H.: Havaintoja lehmien terveydentilasta peruskorjatuissa navetoissa. (Observations on the health of dairy cattle in fundamental repaired cow houses). Maatal. Teknol. Lait. Tutk. Tied. (Inst. Agric. Engin. Rep.) 21, 1-40. Helsinki 1977.

Saloniemi, $H$. \& $K$. Roine: Nautakarjan sairastavuudesta ja karjakoon vaikutuksesta sairastavuuten. (Incidence of illness in dairy cattle with special reference to herd size). Suom. Eläinlääk.-L. 1976, 82, 231-243.

Simensen, E.: Mjølkproduksjon og sjukdom hos storfe i Hedmark fylke. (Milk production and diseases in dairy cattle in Hedmark). Norsk Vet.-T. 1976, $88,640-647$.

Schou, J.: Rententio secundinarum bovis. Nord. Vet.-Med. 1965, 17, $693-702$.

Ødegaard, $S$. A.: Uterine prolapse in dairy cows. A clinical study with special reference to incidence, recovery and subsequent fertility. Acta vet. scand. 1977, Suppl. 63.

\section{SAMMANFATTNING}

Frekvensen av några sjukdomstillstånd $i$ samband med förlossning hos ko.

I 283 besättningar undersöktes under åren 1968-75 förekomsten av följande sjukdomstillstånd i samband med förlossningen: dystocia, prolapsus uteri, retentio secundinarum, metritis puerperalis, prolapsus vaginae. Följande förhållanden observerades: frekvensen/år, frekvensen/månad och dess förhållande till kalvningsfrekvensen och sjukdomsfrekvensen/besättning samt verkan av besättningens storlek och tillhörighet till kontrollverksamhet på sjukdomsfrekvensen.

Frekvensen av dystocia $(0,012 \mathrm{fall} / \mathrm{ko} / \mathrm{a} r)$ och prolapsus uteri $(0,002)$ växlade parellelt med kalvningarnas säsongfrekvens. Retentio secundinarum förekom vanligast under perioden mars-juni $(0,025)$. Detta synes bero på, at kor, som kalva vid denna tid, i medeltal är 
äldre än vid andra tider av året. Den högre frekvensen av kvarbliven efterbörd i små besättningar och sådana, som är underkastade kontroll, kan bero på ägarnas större intresse av att tillkalla veterinär. I de besättningar, som uppvisade ett stort antal ret. sec. förekom också förhållandevis mera mastit, ketos och pares.

Puerperala metriter förekom oftare i stora och kontrollunderkastade besättningar $(0,002)$. Frekvensen av vaginalprolapser $(0,002)$ var högre på våren än säsongvariationen förutsätter. Besättningens storlek och tillhörighet till kontrollverksamhet inverkade inte på sjukdomsfrekvensen i detta fall.

(Received February 4, 1978).

Reprints may be requested from: the Department of Obstetrics and Gynaecology, F-04840 Hautjärvi, Finland. 